\title{
Multicultural Competence Level of University Instructors: A Perspective from a Turkish Context
}

\author{
Aylin Yavas-Bozkurt \\ Gul Eksi \\ Bulent Alci \\ Yildiz Technical University \\ E-mail: aylinyavas@gmail.com,guleksi@gmail.com,bulent_alci@hotmail.com
}

Doi:10.5901/mjss.2013.v4n14p415

\begin{abstract}
All around the world student mobility in higher education is becoming increasingly important. The mobility of university students has created classrooms where there are students with diverse backgrounds. In these multicultural classrooms, it has become essential for university instructors to understand the changing demographics of students. They must be competent enough to deliver a lecture to diverse groups. To help the instructors with their deficiencies it is important to research whether they are capable of managing cultural differences in their classrooms.In Turkey, multicultural education has gained importance. This study examines university instructors' competence in their capability to teach students from diverse backgrounds and determine whether there is a relationship between their multicultural competence level, and their gender, and discipline taught. A quantitative, descriptive survey research design was used. 136 instructors teaching different disciplines at Yıldız Technical University and Marmara University in Turkey participated in the study. The participants were chosen according to random sampling method. It is seen that gender and disciplines taught play a role in multicultural competence.
\end{abstract}

Keywords: Multicultural competence; Multicultural education; Higher education

\section{Introduction}

The student population at the Turkish universities is becoming increasingly diverse. The 2011-2012 academic year ÖSYM ("Öğrenci Seçme Yerleştirme Merkezi" in Turkish, meaning "Student Selection and Placement Center") statistics showed that the number of foreign students registered at the Turkish universities reached 31,170 (ÖSYM, 2012a).

Different factors contributed to this increase in the number of foreign students studying at the Turkish universities. One of these factors is the Erasmus Program (EuRopean Community Action Scheme for the Mobility of University Students), which started in 1987 (Yağcl, Ekinci, Burgaz, Kellecioğlu, \& Ergene, 2007). The Erasmus Program facilitated student mobility in higher education all over Europe. After Turkey became a part of this program in 2004 (Yağcl et all, 2007), the number of foreign students studying in Turkey continually increased. The Bologna Process also contributed to this rise in the number of foreign students studying at the Turkish universities. One of the objectives of the Bologna Process, which aims to create the European higher education area by harmonizing academic degree standards and quality assurance standards throughout Europe for each faculty, is the elimination of remaining obstacles to the mobility of students and teachers (EUA, 2012). In addition, through the initiations of different associations in Turkey such as Islamic Development Bank, or Association for Religious Affairs, foreign students come to Turkey to have their higher education (Kıroğlu, Kesten, \& Elma, 2010). Foreign students who wanted to register in the Turkish universities used to get the University Entrance Examination for Foreign Students, which started in 1981 (ÖSYM, 2012b). However, the number of foreign students in each faculty used to be restricted to $10 \%$ of the total population (Sabah, 2013). When the Higher Education Council (HEC) in Turkey decided to discontinue administering this test, this restriction was eliminated and the decision how to accept foreign students was left to the universities themselves (YOS, 2012).

Currently, the Turkish universities themselves regulate the process to accept foreign students with their university's Senate's Resolutions approved by the HEC. Now, the Turkish universities which accept foreign students can administer their own examination. In addition to foreign students taking the examination administered by each university, there are also foreign students who come within the framework of different international agreements between the Turkish Government and foreign countries. 
As a result of the increase in the number of foreign students at the Turkish universities, classes became more multicultural. Due to the changing demographics of student populations at the Turkish universities, the need for all instructors to better understand and work with students of different cultures productively has become increasingly important. University instructors need to take into consideration the students' experiences, cultural characteristics, and perspectives in order to be able to provide culturally responsive teaching practices. Diversity influences how students learn, thus, makes it necessary for the teacher to create a culturally fair classroom environment. Otherwise, cultural misunderstandings between the teachers and students in the classroom may occur, which may impact students' educational outcomes negatively.

In Turkey research on teacher competence in multicultural teaching has received little attention in the literature. Little research has explored multicultural self-efficacy as a function of university instructors' multicultural competence. However, research on teacher multicultural competence provides a means to determine whether the teacher believes that he or she is capable of in eliminating cultural differences in the classroom. The determination of competence in multicultural teaching will reveal if they are proficient enough to teach in classes with students from different cultural backgrounds. Developing professional development programs on multicultural education can become necessary if a deficiency is detected. Therefore, this study is important to determine university instructors' beliefs in their competence to teach students from diverse backgrounds and determine whether there is a relationship between their competence level, and their age, gender, discipline taught, and teaching experience abroad.

\section{Literature Review}

Constant developments and innovations in today's world require rapid and profound changes in educational systems all over the world. Educational experts have been seeking more effective learning and teaching environments with more productive programs and practices in order to meet the needs of the learners in this continually changing world. The search for how to achieve a better teaching and learning brings about modern educational practices (Duman \& Aybek, 2003). These modern practices strive to relate what students learn at school to their daily lives. It is essential that the knowledge and skills developed at school contribute to solve everyday problems of the learners. Therefore, the widespread belief that equality can be secured through offering the same programs to all learners in similar schools has been questioned as a result of recent educational innovations as each individual has a different life outside the school with different needs. Furthermore, with the influence of humanistic philosophy, the emphasis given to learners as individuals requires educational practitioners to know their learners better. It is now important to be aware of what kind of a life the learners lead out of the school to be able to prepare them a better learning environment. According to Polat (2009), not only the biological and physiological developmental features, but also social and cultural identities of the learners have been gaining ground in modern educational practices.

\subsection{Multicultural education}

In traditional classrooms teachers considered learners the same as one single individual without recognizing their backgrounds, expectations, or needs. These learners were expected to exhibit the behaviors which would be the result of the information provided by their teachers without questioning the accuracy of it. However, in recent practices teachers and students value each other's characteristics and background and assume them as unique individuals. In this respect, differences are considered normal. As a result, teaching practices have increased in parallel with diversity to be able to address each individual learner and the expected behaviors of each student have changed. Therefore, today's teachers must have this perception. In literature, this perception of understanding differences is called 'multicultural education' or 'intercultural education'.

Bank and Bank (1993) define multicultural education as

"... an idea, an educational reform movement, and a process whose major goal is to change the structure of educational institutions so that male and female students, exceptional students, and students who are members of diverse racial, ethnic, and cultural groups will have an equal chance to achieve academically in school (p 3)."

Bennett (2007) defines multicultural education as an approach to educational practices stands on democratic values that promote cultural pluralism. It is a necessity to accomplish educational equality, developing curricula that foster harmony between different ethnic groups, and repelling demanding practices.

Aydın (2006) also indicates that multiculturalism can be considered as the respect to other cultures, and arranging 
educational practices, and supporting international cooperation in order to promote this respect.

When the different definitions of multicultural education are considered concepts such as respecting human rights, tolerating cultural differences, equal educational opportunities, cultural diversity, reflective teaching, arranging environments, analyzing diverse point of views and opinions, it is clear that all these concepts are the common concepts used to define multicultural education (Cırık, 2008).

The basic objective of multicultural education is to increase academic achievement of the students and promote cultural sensibilities and prevent prejudices about cultural differences (Dunn, 1997). Gay (1994) indicates that there are 7 major goals of multicultural education: Developing ethnic and cultural literacy: Being aware of one's own culture together with other cultural and ethnic diversity in the society and respecting them. Personal development: Trying to understand one's own culture deeply and priding in one's ethnic identity. Clarifying values and attitudes: Explaining values and attitudes of people from different cultures so that people from other cultures will know them and respect them. Multicultural social competence: Promoting intercultural communication and identifying diverse cultures, and point of views. Basic skills proficiency: Supporting learners from diverse ethnic groups in order to make them acquire basic skills such as reading and writing, problem solving or critical thinking. Educational equity and excellence: All learners from diverse cultural backgrounds are provided with same opportunities. Otherwise excellence cannot be attained. Personal empowerment for social reform: A change in school will end in society.

These goals cannot be achieved easily. According to Polat (2009), in order to make multicultural education reach its aims all shareholders in the teaching and learning process must take responsibility. Gay (1994) also indicates that anybody in educational practices must actively participate in multicultural education activities. However, the key responsibility sits on the teachers' shoulders as it is the teacher who conducts the program deciding on the appropriate teaching methods, strategies and materials in order to prepare the learning environment and evaluating the students' learning (Polat, 2009). Ameny-Dixon (2004) emphasizes that university administrator and professor should be familiar with diverse cultural elements so that they will be able to provide services equally without any bias.

However Gay (2000) indicates that teachers can have an inclination to exercise their own cultural belief, and overlook the cultural diversity of the students. Cırı (2008) also states that teachers and administrators are prejudiced against multicultural education and multicultural educational practices and they avoid including them in their teaching environment. However, if education is to accomplish more fundamental social change, teachers need to pursue critical attitude about the society (King \& Ladson-Billings, 1990). Therefore, as Aydın (2006) states 'educators should be creative, flexible, sensitive, equitable, and supportive and utilize all available valuable resources for their students'.

\subsection{Multicultural competence}

According to Bennett (2007) teachers must be multiculturally competent so that they can handle the diverse cultures of their students and become a bridge that connects the learners' culture at home to their culture in the classroom. However, what is this multicultural competence and what type of educators are considered as multiculturally competent?

Multicultural competence has various definitions. According to Ameny-Dixon (2004) multicultural competence is the process in which individuals advance in their capabilities to identify, evaluate, comprehend and solve problems in more than one way. In this process the purpose is 'to focus on understanding and learning to negotiate cultural diversity among nations as well as within a single nation by becoming aware of one's own perspectives as well as becoming conscious of other cultural perspectives'(p. 5). Pope and Reynolds (1997) define multicultural competence as having the multicultural awareness, knowledge, and skills essential for creating multicultural environments.

Bennett, Niggle and Stage (1990) outline four different competence for the teachers of multicultural education: (a) knowledge is being aware of the history, culture, and values of different ethnic groups (b) understanding includes having cross-cultural interactions and immersion experiences in which to apply cultural theory, (c) attitude involves being aware of one's own prejudices and misconceptions about race and trying to eliminate them; and (d) skill which includes planning and implementation of effective multicultural teaching practices. Washington (2003), on the other hand, indicated that educators must have 3 major multicultural competences which are self-understanding, understanding others, and academic multicultural proficiency.

Teachers with multicultural competence have superiority over other teachers in many senses. Multicultural competence helps teachers' value diversity (King \& Ladson-Billings, 1990, p. 17). Multiculturally competent teachers navigate through the diverse cultures of their students, and they can become the bridge that connects the students' home culture with their school culture (Bennett, 2007).

Banks (1988) believes that teachers with cultural competency improve their teaching abilities, attitudes, and 
understandings in diverse cultural environments. He states that the 'Global Competency' (p. 69) the individuals attain makes it possible for them to live in a global society. They the values and principles of the community become a part of them, and they consider them while acting in the society.

Aydın (2012) also emphasizes the importance of multicultural education for multicultural activities should be integrated in all curriculum areas, including social studies, language arts, science, humanities, etc. Administrators, teachers, faculties, and staffs should create an educational climate in which different cultural, ethnic, and linguistic patterns are accepted and nourished throughout the curriculum.

Although multicultural education has been such an important issue, as Pope and Mueller (2005) states, there is limited information about the demographic composition of students and faculty members, exploration of multicultural issues within the curriculum, and the multi-cultural competence of faculty and staff. Limited studies focus on determining candidate teachers' and teachers' beliefs of their abilities in teaching culturally diverse classes (Siwatu \& Starker, 2010).

In Turkey the research on multicultural education has progressed in the last 5 years. Especially with the initiatives by the government greater steps have been put forward in tolerance diversity. As multiculturalism has become a hot topic, Turkish researchers (Cırık, 2008; Yazıcı, Başol and Toprak, 2009; Başbay and Kağnıcı, 2011; Özturgut, 2011; Tarman and Tarman 2011; Aydın, 2012; Demir and Başarır, 2013) have been conducting research on different issues in multicultural education.

To be able to contribute the multicultural education literature in Turkey, this research, therefore, aims to determine whether instructors working at the Turkish universities are capable of teaching multicultural classes. Since the programs are conducted by the teachers, they are required to be multiculturally competent (Polat, 2009). As Aydın (2012) states 'administrators, teachers, faculties, and staffs should create an educational climate in which different cultural, ethnic, and linguistic patterns are accepted and nourished throughout the curriculum (p.284). However, the results of the previous studies indicate that university students, instructors and administrators are not proficient enough in multicultural education (Cırık, 2008). Therefore, this study is important to determine multicultural competence of university instructors and illustrate if the results of the previous studies are still valid.

\section{Research Questions}

Accordingly, the research questions of the study are mentioned below:

1. What is the multicultural competence level of instructors working at the Turkish universities?

2. Is there a significant difference between their multicultural competence level and gender?

3. Is there a significant difference between their multicultural competence level and discipline?

\section{Research Methodology}

In this study the multicultural competence level of Turkish university instructors was investigated. A quantitative, descriptive survey research design was used in the study. The participants were selected through convenience sampling. An online survey was used to collect data.

\subsection{Participants}

136 Instructors teaching different disciplines at Yildiz Technical University and Marmara University in Turkey participated in the study. The participants were chosen according to random sampling method. 62 of the participants were male, while 74 of them were female. The ages of the participants ranged from 22 to 61 , and the average age was determined as 33 , 8. 80 research assistants, 37 lecturers, 10 assistant professors, 7 associated professors, and 2 professors participated in the study. Of all these participants, 63 have been abroad for academic studies, whereas 73 of them have not. The number of instructors with teaching experience abroad was determined to be 10 instructors. Due to the wide variety of departments where the participants teach, the independent variable 'department' was coded into two groups as 'technical sciences' and 'social sciences'. 51 of the participants were from technical sciences while 85 of them were from social sciences.

\subsection{Instrument}

Perceptions of Multicultural Competence Scale (Çok Kültürlü Yeterlik Algıları Ölçeği)" designed by Başbay and Kağnıcı 
(2011) was conducted. In the design of Başbay and Kağnıcı (2011), exploratory factor analysis (EFA), a construct with 41 items and 3 factors, namely "Awareness", "Knowledge" and "Skill" was achieved. The relationship among subscales was tested. As a result, a significant positive relationship was found. By the analysis it was seen that subscales were the dimensions of a construct named multicultural competence. Fit indexes of the model were high. In addition, confirmatory factor analysis (CFA) confirmed the results of EFA. The Cronbach's alpha value for the scale was found to be .95 .

This study was conducted after the permission to be able to use and get a soft copy of the scale they developed was taken by an e-mail. As soon as the scale and the necessary permission of the researchers were received, the scale was converted into an online format. The questions to get the demographic information of the participants were not included in the original scale. These questions were added to the original scale by the researchers of the current study. When the online scale was finalized, it was sent to the participants' e-mail addresses to be responded. There were 41 items in the scale. The participants responded by indicating how much they agreed with each item on a five-point Likert scale from 'totally disagree' to 'totally agree'. Participants also responded to some questions to get demographic information about them such as gender, age, department they teach and their academic experience abroad.

\section{Findings and Discussion}

\subsection{Research Question 1 What is the multicultural competence level of instructors working at the Turkish universities?}

The aim of the study is to investigate the multicultural competence level of university instructors. Before running the factor analysis, all the assumptions were checked. Kaiser-MeyerOlkin (KMO) and Barlett's test of sphericity were examined to evaluate the appropriateness of the data for the factor analysis. KMO value must be .6 and above and Bartlett's test should be significant (Tabachnick \& Fidell, 2007). KMO value of 0,89 and Barlett Sephiricity Test $(p<0,001)$ indicated that we could conduct a reliable factor analysis (Kalaycl, 2005, 322).

The factor analysis was performed for the subscales. Varimax rotation was used in this process. The results were similar to the Başbay and Kağnıcı (2011)'s results. On the other hand, four of the items (1st, 5th, 11th, 34th) were excluded from the scale, since the total item correlation was lower than .20 (Büyüköztürk, 2006). As a result, 37 items were left and the Cronbach's alpha value for the scale was found to be, 95 . The reliability values of scales are high for researches in social sciences (Kalaycl, 2006). In addition, the factor values were found to be 21,13 for the first component variance "ability", 14,48 for the second component variance "knowledge", and 14,30 finally for the third component variance "awareness".

Table 1. Descriptive Statistics

\begin{tabular}{|lccc|}
\hline \multicolumn{1}{c}{ Factors } & $\mathrm{N}$ & Mean & Std. Deviation \\
\hline Skill & 136 & 3.85 & .66 \\
Knowledge & 136 & 3.75 & .64 \\
Awareness & 136 & 4.27 & .54 \\
Multicultural competence level (general) & 136 & 3.96 & .55 \\
\hline
\end{tabular}

139 instructors responded to the scale. Their general multicultural competence level was found to be 3,96 . The descriptive statistics show that their awareness of multicultural competence $(4,27)$ is higher than their knowledge $(3,75)$ and skill $(3,85)$ of multicultural competence.

\subsection{Research Question 2 Is there a significant difference between their multicultural competence level and gender?}

Table 2. Results of t-test analysis for Multicultural competence and gender

\begin{tabular}{|c|c|c|c|c|c|c|}
\hline Group statistics & \multicolumn{7}{|c|}{} \\
\hline \multirow{3}{*}{ Multicultural Competence } & Gender & $\mathrm{N}$ & Mean & Std. Dev. & $\mathrm{t}$ & $\mathrm{p}$ \\
\cline { 2 - 8 } & Male & 62 & 3,78 &, 56 & \multirow{2}{*}{$-3,690$} & \multirow{2}{*}{, 000} \\
\cline { 2 - 6 } & Female & 72 & 4,11 &, 50 & \\
\hline
\end{tabular}

In order to determine if the multicultural competence of university instructors show difference or not according to their 
genders, $t$ test was used and statistically meaningful difference was found between these two variables.

5.3 Research Question 3 Is there a significant difference between their multicultural competence level and discipline taught?

Table 3. Results of t-test analysis for Multicultural competence and discipline taught

\begin{tabular}{|c|c|c|c|c|c|c|}
\hline Group statistics & \multicolumn{6}{|c|}{$\mid$} \\
\hline \multirow{3}{*}{ Multicultural Competence } & Department & $\mathrm{N}$ & Mean & Std. Dev. & $\mathrm{t}$ & $\mathrm{p}$ \\
\cline { 2 - 7 } & Social sciences & 85 & 4,05 &, 52 & \multirow{2}{*}{2,438} & \multirow{2}{*}{016} \\
\cline { 2 - 6 } & Natural sciences & 51 & 3,81 &, 58 & & \\
\hline
\end{tabular}

In order to determine if the multicultural competence of university instructors show difference or not according to their departments, $t$ test was used and statistically meaningful difference was found between these two variables.

\section{Conclusions and Recommendations}

Political, economic and especially technological developments result in a dizzying change in the world, which have had a great impact on countries, communities and individuals. As a result, globalism, nationalism, locality, national culture, intercultural convergence, multiculturalism, multicultural competence, multilingualism, intercultural conformity, tolerance among different religions have started to be discussed (Polat, 2009).

The multicultural competence level of Turkish university instructors was investigated in this study. A quantitative, descriptive survey research design was used. The descriptive statistics showed that their awareness of multicultural competence was higher than their knowledge and skill of multicultural competence. This shows the necessity of multicultural education program development for the university instructors. In addition, female instructors were found to have more multicultural competence than male instructors. As Nieto $(2002 ; 2008)$ stated, educators in schools exist within the sociopolitical structures, and they reflect many aspects of society. Banks (1988) believed that teachers who developed cross-cultural competency improved their teaching abilities, attitudes, and understandings in diverse cultural settings. He stated that the "Global Competency" (p. 69) that individuals develop enables them to act within the global society. They internalize the values and principles of humankind, and they know how to act on those values. For that reason, both male and female instructors should have more multicultural competence. The HEC should start some program development studies for the university instructors and pre-service teachers as well.

The university instructors who teach social sciences showed more multicultural competence than the university teachers who teach natural sciences. Multiculturally efficacious teachers find ways of building the bridges for their students (Guyton \& Wesche, 2005). The instructors of natural sciences should have more multicultural efficacy. In line with this, universities should open more space for connection between/among the departments so that social and natural sciences departments' instructors would interact.

Fine and Weiss (2003) stated that cultural conflict occurs when members of the dominant society believe that their culture is the only culture. They perceive others as living and thinking as they do. If there had been multicultural education policy, there would not have been so much conflict in Turkey. When we think the issues in the Turkish context, it is clear to understand that becoming culturally responsive teachers in today's diverse classroom as described by Mitchell, L. A. (2009) should be our main goal in terms of education.

\section{References}

Ameny-Dixon, G. (2004). Why Multicultural Education Is More Important In Higher Education Now Than Ever: A Global Perspective. National Forum: International Journal of Scholarly Academic International Diversity. 6 (4), 1-12

APA (2002). Guidelines on multicultural education, training, research, practice, and organizational change for psychologists - American psychological association. Retrieved from http://www.apa.org/pi/oema/resources/policy/multicultural-guidelines.aspx

Aydın, H. (2006). Eleştirel aklın ışığında postmodernizm, temel dayanakları ve eğitim felsefesi. Eğitimde Politika Analizleri ve Stratejik Araştırmalar Dergisi, 1(1). 277-286.

Aydın, H. (2012). Multicultural education curriculum development in Turkey. Mediterranean Journal of Social Sciences, 3 (3), $277-286$. Doi:10.5901/mjss.2012.v3n3p277

Banks, J. (1988). Multiethnic Education: Theory and practice. Boston: Allyn \& Bacon. 
Banks, J.A., \& Banks, C.A.M. (1993). Multicultural Education: Issues and Perspectives (2nd ed.). Boston: Allyn and Bacon.

Baptiste, H.P. (1979). Multicultural education: A synopsis. Washington, D.C.: University Press of America.

Başbay, A. \& Kağnıcı, D. Y. (2011). Çokkültürlü yeterlik algıları ölçeği: Bir ölçek geliştirme çalışması. Eğitim ve Bilim,161, $199-212$.

Başbay, A. \& Kağnıcı, D.Y. \& Sarsar, F. (2013). Eğitim fakültelerinde görev yapmakta olan öğretim elemanlarinin çokkültürlü yeterlik algilarinin incelenmesi. Turkish Studies Dergisi, 8 (3) 47-60. Retrieved on May 29, 2013 from

http://www.turkishstudies.net/Makaleler/1710349915_4Ba\%C5\%9FbayAlper_47-60.pdf

Büyüköztürk, S. (2006). Sosyal bilimler için veri analizi el kitabi: istatistik, arastirma deseni SPSS uygulamalari ve yorum. Ankara: Pegem A Yayincilik.

Bennett, C. I. (2007). Comprehensive multicultural education (6th ed.). Boston: Pearson.

Bucher, R. (2000). Diversity Consciousness (1st ed.). New Jersey: Prentice-Hall.

Cırık, İ. (2008). Çok Kültürlü Eğitim ve Yansımaları. Hacettepe Üniversitesi Eğitim Fakültesi Dergisi. 34, 27-40

Demir S. and Başarır F. (2013). Çok Kültürlü Eğitim Çerçevesinde Öğretmen Adaylarının Öz-Yeterlik Algılarinin İncelenmesi. International Journal of Social Science. 6(1), 609-641

Duman, B. ve Aybek, B. (2003). Süreç temelli ve disiplinlerarası öğretim yaklaşımlarının karşılaştırılması. Muğla Üniversitesi SBE dergisi,11,1-12.

Dunn, R. (1997). The goals and track record of multicultural education. Educational Leadership, 54(7), 74-77. EUA (2012). Retrieved from http://www.eua.be/eua-work-and-policy-area/building-the-european-highereducation-area/bologna-basics/Bologna-anoverview-of-the-main-elements.aspx

Födda, F. (1997). Om våra mänskliga rättigheter - metodpärm för lärare. Amnesty International,MOD, Röda Korset, Utbildningsradion. Skara. Retrieved from http://www.amnesty.org.tr/ai/system/files/herinsanozgurdogar.pdf

Gay, G. (1994). A synthesis of scholarship in multicultural education. North Central Regional Educational Lab. OakBrook, IL: Urban Monograph Series. Retrieved May 21, 2013 from http://www.ncrel.org/sdrs/areas/issues/educatrs/leadrshp/le0gay.htm

Gay, G. (2000). The importance of multicultural education. Educational Leadership, 61(4).

Guyton, E. M., \& Wesche, M. V. (2005). The multicultural efficacy scale: Development, item selection, and reliability. Multicultural Perspectives, 7(4), 21-29.

Kalayci, S. (2006). SPSS uygulamali çok degiskenli istatistik teknikleri. Ankara: Asil Yayin Dagitim.

Kıroğlu, K., Kesten, A., \& Elma, C. (2010) Türkiye'de Öğrenim Gören Yabancı Uyruklu Lisans Öğrencilerinin Sosyo-Kültürel ve Ekonomik Sorunları, Mersin University Journal of the Faculty of Education, 6 (2), 26-39.

King, J.E., \& Ladson-Billings, G. (1990). The teacher education challenge in elite university settings: Developing critical perspectives for teaching in a democratic and multicultural society. European Journal of Intercultural Studies, 1, 15-30.

McGeehan, J. (1982, March). The relationship of selected antecedent variables to outcomes of training in multicultural education for preservice teachers. Paper presented at the meeting of the American Educational Research Association, New York.

Mitchell, L. A. (2009). Becoming culturally responsive teachers in today's diverse classroom. Paper presented at the 2009 American Educational Research Association Annual Meeting, San Diego, CA.

Nieto, S. (2002). Language, culture, and teaching: Critical perspectives for a new century.

Mahwah, NJ: Lawrence Erlbaum. Nieto, S., \& Bode, P. (2008). Affirming diversity: The sociopolitical context of multicultural education (5th ed.). Boston: Pearson.

ÖSYM. (2012a). Retrieved from http://www.osym.gov.tr/dosya/1-60408/h/21yabanciogrenciuyruk.pdf

ÖSYM. (2012b) Retrieved from http://www.osym.gov.tr/belge/1-6147/1983-1974-yillari-arasindakisinavlar.html

Özturgut, O. (2011). Understanding multicultural education. Current Issues in Education, 14(2). 1-8.

Polat, S. (2009). Öğretmen Adaylarının Çok Kültürlü Eğitime Yönelik Kişilik Özellikleri. International Online Journal of Educational Sciences. 1 (1), 154-164.

Pope, R L, \& Reynolds, A. L. (1997). Student affairs core competencies: Integrating multicultural awareness, knowledge, and skill. Journal of College Student Development. 38, 266-277

Pope, R. L., \& Mueller, J. A. (2005). Faculty and curriculum. Examining multicultural competence and inclusion. Journal of College Student Development, 46(6), 679-688.

Sabah. (2013). Retrieved from http://www.sabah.com.tr/Egitim/2013/02/25/turk-universitelerine-yabanci-ogrenci-ilgisi

Siwatu, K.O.and Starker, T.V. (2010). Predicting Pre-service Teachers Self efficacy to Resolve a Cultural Conflict Involving an African American Student, Multicultural Perspectives. 12(1), 10-17

Tabachnick \& Fidell, (2007). Using multivariate statistics (5th ed.). Boston: Allyn and Bacon.

Tarman I. and Tarman B. Developing Effective Multicultural Practices: A Case Study Of Exploring A Teacher's Understanding And Practices. Uluslararası Sosyal Araştırmalar Dergisi. 4(17). 578-598.

Washington, E.D. (2003). The multicultural competence of teachers and the challenge of academic achievement. Donald B. Pope-Davis, H. L.K. Coleman, W. M. Liu, and R. L. Toporek (Eds.). Handbook of multicultural competencies in counseling and psychology (440-464). California: Sage Publications.

Yağcı, E., Ekinci, C.E., Burgaz, B., Kellecioğlu, H., \& Ergene T. (2007) Yurt dışına giden hacettepe üniversitesi erasmus öğrencilerinin memnuniyet düzeyleri. Hacettepe University Journal of Education, 33, 229-239.

Yazıcı S., Başol G. and Toprak G. (2009). Öğretmenlerin Çokkültürlü Eğitim Tutumlari: Bir Güvenirlik Ve Geçerlik Çalışmasi. Hacettepe Üniversitesi Eğitim Fakültesi Dergisi. 37: 229-242 
